\title{
An Assessment of Core Competencies among the Employees working in Manufacturing Sector
}

\author{
B.Mohana Priya ${ }^{1}$, Dr.N.Shanmughavadivu ${ }^{2}$ \\ ${ }^{1}$ Research Scholar - Department of Social Work, Bharathiar University, Coimbatore, Tamilnadu \\ ${ }^{2}$ Assistant Professor - Department of Social Work, Bharathiar University, Coimbatore, Tamilnadu
}

\begin{abstract}
Competency is a set of skills, Knowledge and ability to perform the task in order to achieve the goal. The assessment of competency among the employees working in the manufacturing sector plays a major role for the success of the individual and the organization. So, the researcher attempted the research on Core competencies among the employees working in manufacturing sector. The objective of the study is to analyze the core competencies and the level of the core competency. The universe of the study is employees working in manufacturing sector in Cosmafan Foundry Park1, Arasur, Coimbatore. The researcher used Accidental sampling method to collect the data from 95 respondents. The self - structured questionnaire is adopted for the study. The data collected is coded and analyzed using the Statistical Package for Social Science (SPSS). The competency level of the employees can be improved by providing the training and career development programmes to the employees at regular interval of time.
\end{abstract}

Keywords: Competency, Knowledge, Skill

\section{INTRODUCTION}

Competency is the capability if individuals behaviour, various parameters required for the job listed by the organization to achieve the goals. Hogg B (1989) states that "competencies are the characteristics of a manager that lead to the demonstration of skills and abilities, which result in effective performance within an occupational area. Competency also embodies the capacity of transfer skills and abilities from one area to another ". Core competencies will differentiate the individual from others in the organization and also among the competitors. The combination of resources and capabilities to make the strategic development leads the way to succeed. The competency aligned for the particular job helps to differentiate the level of the performance of the employed individuals.

\section{REVIEW OF LITERATURE}

Lin, Y. (2021) carried out "A study on the relationship between project management competency, job performance and job motivation in e-commerce industry". A questionnaire is prepared and collected the data from 320 respondents, the results interprets that, project management competency had positive influence over the performance among the employees working in e- commerce sector.

Potnuru, R.K.G., Sahoo, C.K. and Sharma, R. (2019) undergone a research on "Team building, employee empowerment and employee competencies: Moderating role of organizational learning culture. The researcher moderated the model using Moderated Structural Equational Modelling and collected the data from 653 employees who employed in cement manufacturing industry. The researcher attempted to study the impact of team building and employee empowerment on employee competencies.

Safavi, H. P., \& Bouzari, M. (2019) studied the association of psychological capital, career adaptability and career competency among hotel frontline employees. The data was collected among 193 employees in five start hotels in North Cyprus in a two weeks' time. The results states that, there was a significant relationship between psychological capital and career adaptability, which in turn have a positive impact over the competency also. The research concludes that career adaptability mediates the relationship between competency and psychological capital.

Karami, A., Farokhzadian, J., \& Foroughameri, G. (2017) carried out the research among Nursing professional competency and organizational commitment: Is it important for human resource management. The data was collected among 230 nurses in Iran using stratified random sampling method. Competency inventory for nurses and organizational commitment scale is used for the study. The results highlight the need of core competency for nurse and their commitment for the organizational development. Based on this study, the researcher suggested the Human resource management department to suggest strategies for the development of the individual and organization. 
DOI: 10.17148/IARJSET.2021.8954

\section{RESEARCH METHODOLOGY}

The aim of the research is to study the level of core competency among employees working in manufacturing sector. The systematic description about the research design is taken or this research. The universe of the study is employees working in the manufacturing sector in Cosmafan Foundry Park1, Arasur, Coimbatore. The researcher adopted an Accidental sampling, a non- probability sampling method in which from a population a sample is drawn which is close to the hand for data collection The researcher collected the data from 95 respondents.

The self- structured questionnaire is prepared for data collection. The questionnaire consists of questions related to personal details and another section of question pertaining to core competency. The Likert scale is used to mark the responses. The questionnaire method is employed to collect the data from the respondents. The collected data is transferred into master data sheet, coded and analysed using the SPSS (Statistical package for Social Sciences).

\section{DATA ANALYSIS AND INTERPRETATION}

Table 1: Personal Details

\begin{tabular}{|l|l|l|l|}
\hline S.No. & Variable & Frequency & Percentage \\
\hline $\mathbf{1}$ & Age (in Years) & & \\
\hline & $21-30$ & 53 & $55.7 \%$ \\
\hline & $31-40$ & 35 & $36.9 \%$ \\
\hline & $41-50$ & 7 & $7.4 \%$ \\
\hline & TOTAL & 95 & $100 \%$ \\
\hline $\mathbf{2}$ & Experience & & \\
\hline & LESS THAN 2 YEARS & 13 & $13.69 \%$ \\
\hline & 2 TO 3 YEARS & 45 & $47.36 \%$ \\
\hline & 4 TO 5 YEARS & 32 & $33.68 \%$ \\
\hline & 6 TO 7 YEARS & 5 & $5.27 \%$ \\
\hline & TOTAL & 95 & $100 \%$ \\
\hline $\mathbf{3}$ & Shift & & \\
\hline & ROTATIONAL & 90 & $94.73 \%$ \\
\hline & GENERAL & 5 & $5.27 \%$ \\
\hline & TOTAL & 95 & $100 \%$ \\
\hline
\end{tabular}

The above table shows that majority of the respondents are in the age group of 21-30 years which predicts that they are fresh to work or they may have only less experience. As it is a manufacturing sector $94.73 \%$ are working in rotational shift.

Table 2: Levels of Core Competencies

\begin{tabular}{|l|l|l|}
\hline $\begin{array}{l}\text { ADAPTABILITY } \\
\text { COMPETENCE }\end{array}$ & FREQUENCY & PERCENTAGE \\
\hline LOW (6 to 22) & 9 & $9.47 \%$ \\
\hline MEDIUM (23 to 26) & 72 & $75.78 \%$ \\
\hline HIGH (27 to 30) & 14 & $14.75 \%$ \\
\hline Total & 95 & $100 \%$ \\
\hline INITIATIVE & FREQUENCY & PERCENTAGE \\
\hline LOW (6 to 23) & 14 & $14.73 \%$ \\
\hline MEDIUM (24 to 26) & 65 & $68.42 \%$ \\
\hline HIGH (27 to 30) & 16 & $16.85 \%$ \\
\hline TOTAL & 95 & $100 \%$ \\
\hline JUDGEMENT & FREQUENCY & PERCENTAGE \\
\hline LOW (5 to 18) & 10 & $10.52 \%$ \\
\hline MEDIUM (19 to 22) & 69 & $72.63 \%$ \\
\hline HIGH (23 to 25) & 16 & $16.85 \%$ \\
\hline TOTAL & 95 & $100 \%$ \\
\hline $\begin{array}{l}\text { PLANNING } \\
\text { ORGANIZATION }\end{array}$ & FREQUENCY & PERCENTAGE \\
\hline LOW (6 to 23) & 16 & $16.84 \%$ \\
\hline
\end{tabular}


International Advanced Research Journal in Science, Engineering and Technology

Vol. 8, Issue 9, September 2021

DOI: 10.17148/IARJSET.2021.8954

\begin{tabular}{|l|l|l|}
\hline MEDIUM (24 to 26) & 71 & $74.73 \%$ \\
\hline HIGH (27-30) & 8 & $8.43 \%$ \\
\hline TOTAL & 95 & $100 \%$ \\
\hline PROBLEM SOLVING & FREQUENCY & PERCENTAGE \\
\hline LOW (5 to 19 ) & 19 & $20 \%$ \\
\hline MEDIUM (20 to 22) & 54 & $56.84 \%$ \\
\hline HIGH (23 to 25) & 22 & $23.16 \%$ \\
\hline TOTAL & 95 & $100 \%$ \\
\hline LEADERSHIP QUALITY & FREQUENCY & PERCENTAGE \\
\hline LOW (5 to 18 ) & 7 & $7.36 \%$ \\
\hline MEDIUM (19 to 22) & 68 & $71.57 \%$ \\
\hline HIGH (23 to 25) & 20 & $21.07 \%$ \\
\hline TOTAL & 95 & $100 \%$ \\
\hline PRODUCTIVITY & FREQUENCY & PERCENTAGE \\
\hline LOW (6 to 22) & 9 & $9.47 \%$ \\
\hline MEDIUM (23 to 26) & 76 & $80 \%$ \\
\hline HIGH (27 to 30) & 10 & $10.53 \%$ \\
\hline TOTAL & 95 & $100 \%$ \\
\hline USE OF TECHNOLOGY & FREQUENCY & PERCENTAGE \\
\hline LOW (4 to 15$)$ & 10 & $10.52 \%$ \\
\hline MEDIUM (16 to 17$)$ & 58 & $61.05 \%$ \\
\hline HIGH (18 to 20) & 27 & $28.43 \%$ \\
\hline TOTAL & 95 & $100 \%$ \\
\hline
\end{tabular}

The above table shows the level of the various dimensions of the competency which includes Adaptability competence, Initiative competence, Judgement competence, Planning and organization, Problem solving, Leadership quality, Productivity competence and usage of technology of the respondents. . Most of the respondents are in the medium level so that if we provide a proper training to the employees we can enrich them.

\section{FINDINGS}

More than half of the respondents are under the age category of 21-30 years (55.7\%). Nearly half of the respondents have work experience in the organization between 2-3 years (47.36\%). Majority of the respondents are in their rotational shift $(94.73 \%)$. Majority of the respondents have earlier work experience in the present job (88.43\%).

Majority of the respondents have medium level of Adaptability competence $(75.78 \%)$. Majority of the respondents have medium level of Initiative competence (68.42\%). Nearly three fourth of the respondents have medium level of Judgment competence $(72.63 \%)$. Majority of the respondents have medium level of Planning \& Organization competence (74.73\%). More than half of the respondents have medium level of Problem Solving competence (56.84\%). Majority of the respondents have medium level of Leadership quality competence (71.57\%). More than three fourth of the respondents have medium level of Productivity competence $(80 \%)$. Majority of the respondents have medium level of Use of Technology competence $(61.05 \%)$

To find out the association, chi square test is employed. There is no association between age, gender, qualification, experience of work and shift with core competency.

\section{SUGGESTIONS}

In order to strengthen the competency of the employees in future employees should be concentrated and should be enhanced by providing the exclusive training for the employees in their specialized area, Career development of the individuals are highly focussed in the work place, feedback system and performance management system of the organization should be thickened, Stimulation exercises pattern can be inculcated to enrich the knowledge.

\section{CONCLUSION}

Many advanced companies are starting to adopt the use of competencies as an essential management technology to enhance their competitiveness. It is important to build the competency model, where it's applied to human resource systems. The existing matrix is used to measure competency at different levels of employees, not specified with the 


\section{International Advanced Research Journal in Science, Engineering and Technology}

Vol. 8, Issue 9, September 2021

DOI: 10.17148/IARJSET.2021.8954

department and their functions. Therefore, it would be better if it is constructed for employees based on the departmental functions.

\section{REFERENCES}

1. Karami A, Farokhzadian J, Foroughameri G (2017) Nurses' professional competency and organizational commitment: Is it important for human resource management? PLoS ONE 12(11): e0187863. https://doi.org/10.1371/journal.pone.0187863

2. Krishnaveni, J. (2013). A study on mapping of employees' competency. Indian Journal of Economics and Development, 1(3), 71-75.

3. Lin, Y. (2021), "A study on the relationship between project management competency, job performance and job motivation in e-commerce industry", Measuring Business Excellence, Vol. 25 No. 1, pp. 24-57. https://doi.org/10.1108/MBE-10-2020-0144

4. Potnuru, R.K.G., Sahoo, C.K. and Sharma, R. (2019), "Team building, employee empowerment and employee competencies: Moderating role of organizational learning culture", European Journal of Training and Development, Vol. 43 No. 1/2, pp. 39-60. https://doi.org/10.1108/EJTD-082018-0086

5. Safavi, H. P., \& Bouzari, M. (2019). The association of psychological capital, career adaptability and career competency among hotel frontline employees. Tourism management perspectives, 30, 65-74. 